\title{
THE INFLUENCE OF CRYOTHERAPY ON THE LOWER LIMB SPASTICITY FOR CHILDREN WITH CEREBRAL PALSY
}

\author{
Saulė Sipavičenė ${ }^{1}$, Antanas Damašauskas² ${ }^{2}$ Irina Kliziené $\dot{~}^{3}$, Gražina Krutulytè ${ }^{1}$, \\ Aiva Karpavičiené ${ }^{1}$, Tadas Česnaitis ${ }^{4}$ \\ Lithuanian Academy of Physical Education ${ }^{1}$, Kaunas, Lithuania \\ Vilijampole Social Care Homes ${ }^{2}$, Kaunas, Lithuania \\ Kaunas University of Technology3, Kaunas, Lithuania \\ Hospital of Lithuanian University of Health Sciences Kauno Klinikos ${ }^{4}$, Kaunas, Lithuania
}

\begin{abstract}
Research background and hypothesis. Cryotherapy could reduce spasticity for children with cerebral palsy.

Research aim. The aim of this study was to determine the effect of cryotherapy on the lower limb spasticity for children with cerebral palsy.

Research methods. Fourteen children with cerebral palsy spastic Diplegia aged 6-12 years were examined. The procedures of cryotherapy and physical therapy were applied to children in the test group $(n=7)$, and only physical therapy - for the members in the control group $(n=7)$. For all the subjects, the following procedures were performed before and after the research: foot extension measurements, the determination of the spasticity of flexors and selective foot motion, the estimation of balance and gross motor functions.

Research results. After physical exercises foot extension showed improvement, spasticity of foot flexors reduced, foot selective movements, balance and gross motor functions improved. There was no statistical difference between the results in both groups.

Discussion and conclusions. The influence of cryotherapy on the lower limb spasticity for children with cerebral palsy was not statistically significant.
\end{abstract}

Keywords: spasticity, cryotherapy, physical exercises.

\section{INTRODUCTION}

I

has been estimated that there are more than 15 million people with cerebral palsy $(\mathrm{CP})$ in the world. According to PSO statistical data, CP is diagnosed for 1-2 cases of 1000 living newborn children. However, the prevalence of $\mathrm{CP}$ in different countries varies $-1.5-2.5$ cases for 1000 newborns (Paneth et al., 2006).

Spastic CP is the most common type of Cerebral Palsy with about $70-80 \%$ of all diagnosed cases (Nordmark et al., 2001). It is the most common cause of children disability that limits movements and thus distorts their social functioning. Therefore, one of the main challenges in the treatment of such children is the reduction of spasticity.

Despite the fact that $\mathrm{CP}$ is incurable, the development of medical technology holds forth a hope that the disability caused by neurological impairment would sooner or later be reduced or overcome. The pursuance of non-pharmaceutical remedies for the treatment of $\mathrm{CP}$ leads to an increased consideration of physical factors. Cooling is one of it (Lee et al., 2002). Much information has been recently gathered on the positive dosed direct physical, reflex and neurohumoral effect of cooling 
on the human body. Research literature review shows that the method of cryotherapy for reducing spasticity for children with a CP form has not been investigated enough.

The aim of this research was to determine the effect of cryotherapy on the lower limb spasticity for children with cerebral palsy.

\section{RESEARCH METHODS}

Subjects. The study included fourteen 6-12-year-old children with CP spastic Diplegia. The subjects were randomly subdivided into two groups. According to the children's age, both the test and the control groups were homogeneous: $\mathrm{p}=0.871$. In accordance with the gross motor functional classification (Palisano et al., 2007), the first and the second functional levels were determined to all research participants. The study was carried out following the ethical principles of biomedical research outlined in the Declaration of Helsinki.

The procedures of cryotherapy and physical therapy were applied to the children in the test group, and only physical therapy - for the members of the control group.

Measuring foot extension. In order to evaluate the subjects' passive shinbone foot joint movements, the foot extension was performed using goniometer. The measures were taken while the subject was sitting on a couch with their legs bent down at $90^{\circ}$ angle. The measurement plane was sagittal; the measurement axis was underside the foot, the immobile part of goniometer was placed along the fibula, and the mobile part - along the fifth ossa pedis. The initial position of shinbone foot joint was its anatomical position $\left(0^{\circ}\right.$ angle movement in a joint) (Latella, Meriano, 2003).

Foot flexing muscle spasticity evaluation. While evaluating the spasticity of foot flexors, the 6-point modified "Ashworth scale of Muscle Spasticity" (MAS) was applied: passive shinbone foot joint flexion and extension movements at the average pace were performed and resistance was estimated (Mutlu et al., 2008).

Selective foot motion determination. For the determination of selective foot motion we applied the methodology suggested by R. Boyd and H. Graham (1999). The voluntary active movement of feet extension was evaluated on a 5-point scale while the subject was lying on his back on a couch (Boyd, Graham, 1999).
Measuring balance. For the evaluation of the subjects' balance, the children's balance scale was used (Franjoine et al., 2003).

Measuring gross motor functions. Gross motor functions were measured applying the gross motor function scale for children with CP (Russell et al., 2002).

Cryotherapy. Massage of the dorsal part of shins using ice-cubes was applied, as well as 10-minute massage for one limb, once a day, 5 times a week.

Physical therapy program applied. All subjects had 30 minutes of physical exercises once a day, 5 times per week (20 procedures in total).

The program of physical therapy included: normalisation of muscle tonicity by mobilising soft tissues (Manheim, 2008), activation of weak muscles emphasizing the intensifying strength of femoral and foot muscles (Damiano et al., 2008); the expansion of movement amplitude, the improvement of joint mobility applying stretching exercises, the improvement of trunk control (the activation of trunk muscles, the stimulation of tone muscles, the inhibition of compensatory movements, the rehabilitation of neutral trunk physiologic position) (Bobath B., Bobath K., 1990), the development of balance reactions and variability of movement under different conditions (Freeman, 2007); the amplification of foot and tarsus stability while standing and walking (training of physical support and step-phase), the development of gait components in a changing environment.

The research protocol. For all the subjects, the following procedures were performed before and after the research: foot extension measurement, determination of the spasticity of flexors and selective foot motion, estimation of balance and gross motor functions.

Statistical analysis. The research data were processed using SPSS 13.0 computer program. We used the Pearson's Chi square $\left(\chi^{2}\right)$ criterion for the verification of qualitative variable relation hypothesis. For the assessment of the target indications arithmetic averages and their errors were calculated. The Shapiro-Wilc test was used to verify the regularity of continuous variable distribution. In order to identify the differences between two independent groups, we used the Mann-Whitney U test; between related groups Wilcoxon criteria. While verifying statistical hypothesis, the following significance levels were 
applied: $*-p<0.05$ (significant); ${ }^{*}-\mathrm{p}<0.01$ (very significant).

\section{RESEARCH RESULTS}

After the assessment of goniometric measurements it was ascertained that in both the test and the control groups the measurements of foot extension taken before and after the physiotherapy were statistically different (in the test group $\mathrm{p}<0.01$, and in the control group $-\mathrm{p}<0.05$ ).

Changes in feet extension measures were observed in the test group: $1.90 \pm 0.68$ degrees (right foot) and $1.30 \pm 0.72$ degrees (left foot). The test group after physical exercises and cryotherapy procedures showed greater changes in feet extension measures than the group which had only physical exercises. However, the difference between the control and the test groups was not statistically significant (Figure 1).

Changes in the spasticity of feet flexors in the test group were greater and statistically significant $(\mathrm{p}<0.05): 0.4 \pm 0.32$ points (right foot) and $0.40 \pm 0.32$ points (left foot). The change in the control group was less and statistically insignificant: $0.2 \pm 0.26$ points (right foot) and $0.40 \pm 0.32$ points (left foot). However, the difference between the control and the test groups was not statistically significant (Figure 2).

Changes in selective feet movement measurements in the test group were greater and statistically significant: $(\mathrm{p}<0.05): 0.40 \pm 0.32$ points (right foot) and $0.50 \pm 0.33$ points (left foot). The changes in the control group were less and statistically insignificant: $0.20 \pm 0.16$ points (right foot) and $0.20 \pm 0.16$ points (left foot). The
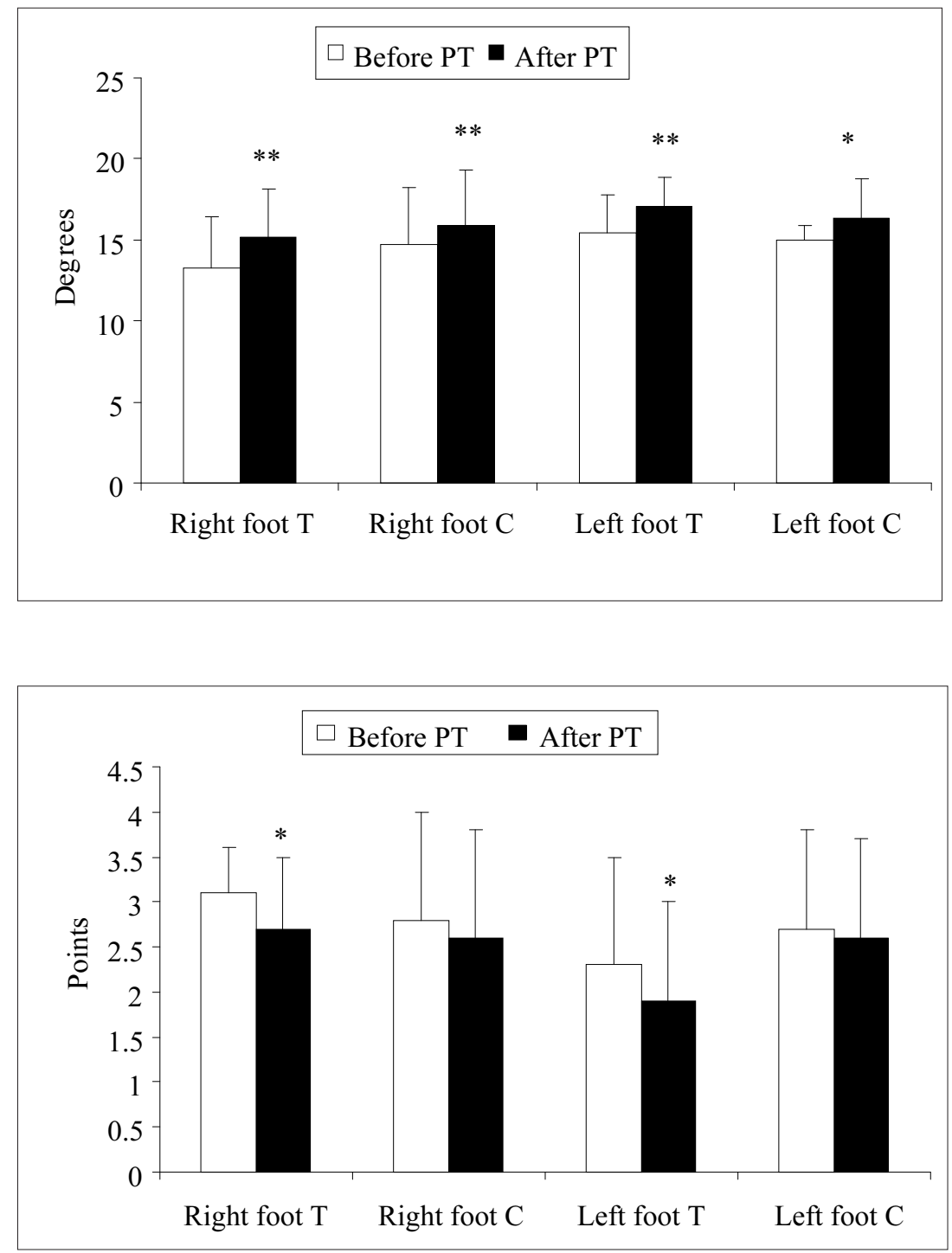

Figure 1. Changes in feet extension measures observed in the control $(C)$ and the test $(\mathrm{T})$ groups

Note. $*-p<0.05$ and $* *-p<0.01$ compared to the values before and after physiotherapy (PT).

Figure 2. Changes in the spasticity of foot flexors in the control (C) and the test (T) groups

Note. ${ }^{*}-\mathrm{p}<0.05$ compared to the values before and after physiotherapy (PT). 
Figure 3. Changes in selective feet movement measurements in the control $(\mathrm{C})$ and the test (T) groups

Note. ${ }^{*}-\mathrm{p}<0.05$ compared to the values before and after physiotherapy (PT).
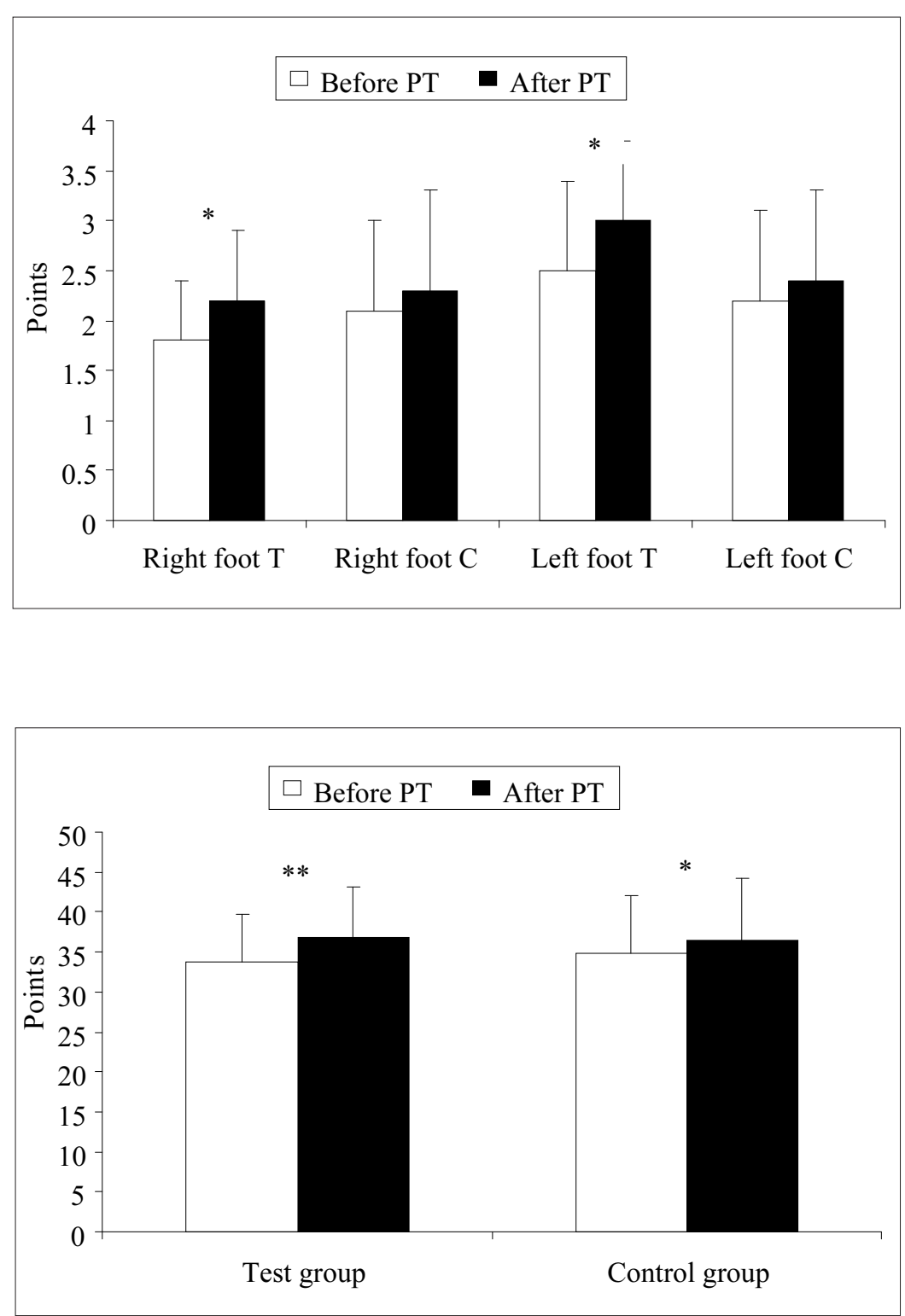

Figure 5. Changes in gross motor function measurements by general scale in the control and the test groups

Note. $* *-p<0.01$ compared to the values before and after physiotherapy (PT).
Figure 4. Changes in balance evaluation values in the control and the test groups

Note. ${ }^{*}-\mathrm{p}<0.05$ and ${ }^{* *}-\mathrm{p}<0.01$ compared to the values before and after physiotherapy (PT).

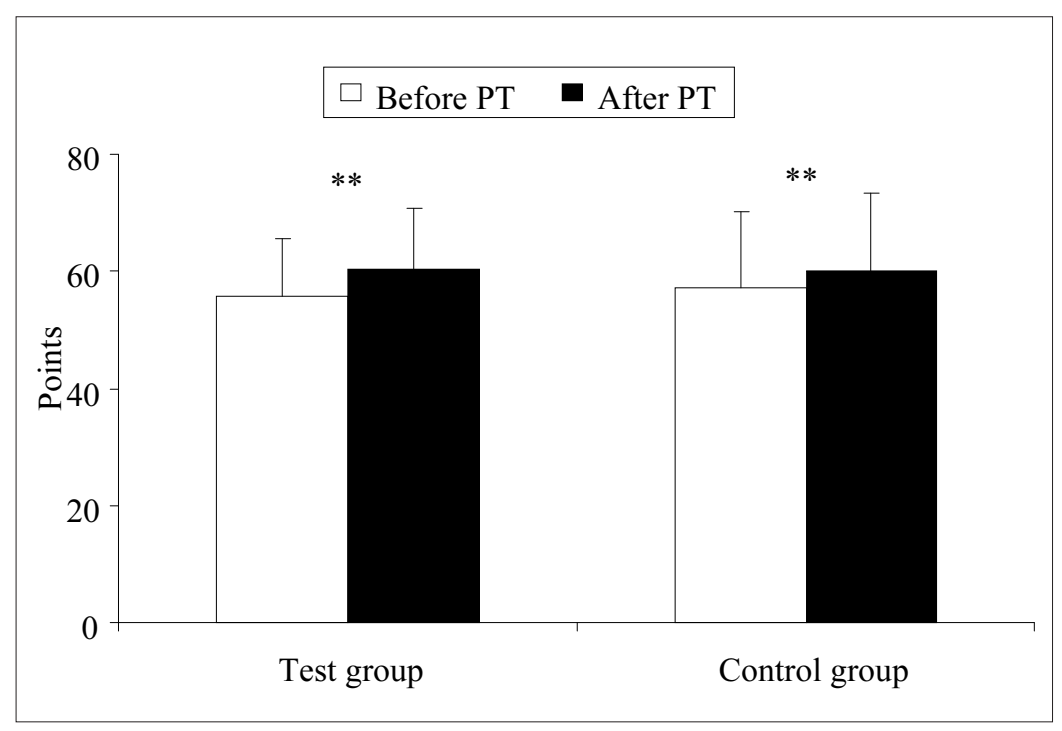


difference between the control and the test groups was statistically insignificant (Figure 3).

Changes in the evaluation of balance in the test group were $3.00 \pm 0.77$ points $(\mathrm{p}<0.01)$, whereas in the control group they were $1.60 \pm 0.67$ points $(\mathrm{p}<0.05)$. The test group which had undergone cryotherapy procedures and physical exercises showed greater changes in balance evaluation measurements than the group which had only physical exercises. However, the difference between the control and the test groups was statistically insignificant (Figure 4).

Changes in the gross motor function measurements by general scale were greater in the test group: $4.73 \pm 0.85$ points $(\mathrm{p}<0.01)$, whereas in the control group they were $2.80 \pm 0.33$ points $(\mathrm{p}<0.01)$. However, the difference between the control and the test groups was statistically insignificant (Figure 5).

\section{DISCUSSION}

The main findings of our study are: 1) after physical therapy programs foot extension of children with CP showed improvement, spasticity of foot flexors reduced, foot selective movements, balance and gross motor functions improved; 2) comparing the effectiveness of different physical therapy programs it was determined that there was no statistical difference between the results in both groups.

Much research has been carried out to evaluate the influence of physiotherapy on children with spastic CP. It has been shown that physical exercises normalize muscle tone (Akbayrak et al., 2005.; Salem et al., 2010), increase the amplitude of movements (Dimitrijevic et al., 2007; Damiano et al., 2010), improve balance (Katz-Leurer et al., 2009) and gross motor functions (Eek et al., 2008; Lee et al., 2008). We were unable to find any research about the influence of cryotherapy on the spasticity of lower limbs of children with spastic CP.

The sample included 1 and 2 functional-level children who were able to move individually or with a little help, and their feet amplitude was slightly irregular. Measures of foot extension increased in both groups, however, no significant and reliable changes were found between the test group which had cryotherapy procedures (cryomassage) combined with physical exercises and the control group which did only physical exercises.

Evaluation measures of balance and gross motor functions improved in both groups; however, no statistically significant difference between these groups was observed.

The analysis of our results showed that after 20 procedures there was a difference between the influence of different physiotherapy programs on the spasticity of foot flexors and selective foot movements in the test and the control groups. The difference in the research data (before and after physiotherapy) was statistically significant only in the test group. In the control group and between both groups no statistically significant differences were observed. Additional intervention is required when physiotherapy is not effective enough. Spasticity is usually treated when it causes loss of function, contracture, deformations, and pain. Application of cryotherapy for affected muscles at appropriate intervals, time-span and temperature reduces pain and spasticity (Stepanchenko et al., 1988; Allison, Abraham, 2001). When cooling, pain receptors located in the skin reduce sending response to CNS, consequently pain is reduced. The purpose of all healing procedures is to reduce extension reflex. Cryotherapy results in reducing monosynaptic extension reflexes and sensitivity of receptors, shaping mediators' influence on reflex arc synapses, blocking neuromuscular junction or motor nerve, which composes reflex arc. This effect lasts even after the cryotherapy procedure (Draper, Knight, 2007).

To achieve the desired result without any damage, one must know the following about the application of cooling (Knight, 1995): physiological effect, side effect, technique of application, affected area, the length of treatment, the number of procedures per day, per week and the total number of procedures.

\section{CONCLUSIONS AND PERSPECTIVES}

To sum up, it is worth noting that both physical therapy programs (combining cryotherapy with physical exercises and performing only physical exercises) had a significant positive effect, however, the effect was not the same.

An important problem in evaluating the effectiveness of physiotherapy is lack of objective research instruments which would help to identify even slight changes in motor function. Children with $\mathrm{CP}$ may show an improvement in motor skills but research instruments not always can identify it (Majnemer, Mazer, 1995). Examining 
such children, large population heterogeneity and inadequate number of subjects have been noticed which caused statistical inadequacies (Grimm, 2000). The mentioned problem was relevant to this research, too.
In conclusion, our findings suggest that the influence of cryotherapy on the lower limb spasticity for children with cerebral palsy was not statistically significant.

Statement of conflict of interest. The authors report no conflict of interest.

\section{REFERENCES}

Akbayrak, T., Armutlu, K., Gunel, M. K., Nurlu, G. (2005). Assessment of the short-term effect of antispastic positioning on spasticity. Pediatrics International: Official Journal of the Japanese Pediatric Society, 47, 440-445.

Allison, S. C., Abraham, L. D. (2001). Sensitivity of qualitative and quantitative spasticity measures to clinical treatment with cryotherapy. International Journal of Rehabilitation Research, 24, 15-24.

Bobath, B., Bobath, K. (1990). Adult Hemiplegia: Evaluation and Treatment. London: Heinemann Medical Books.

Boyd, R., Graham, H. (1999). Objective measurement of clinical findings in the use of Botulinum toxin type A for the management of children with cerebral palsy. European Journal of Neurology, 6, 23-35.

Damiano, D. L., Alter, K. E., Chambers, H. (2008). New clinical and research trends in lower extremity management for ambulatory children with cerebral palsy. Physical Medicine and Rehabilitation Clinics of North America, 20, 469-491.

Damiano, D. L., Arnold, A. S., Steele, K. M., Delp, S. L. (2010). Can strength training predictably improve gait kinematics? A pilot study on the effects of hip and knee extensor strengthening on lower-extremity alignment in cerebral palsy. Physical Therapy, 90, 269-279.

Dimitrijevic, L., Stankovic, I., Zivkovic, V. et al. (2007). Botulinum toxin type A for the treatment of spasticity in children with cerebral palsy. Vojnosanitetski Pregled. Military-Medical and Pharmaceutical Review, 64, 513518.

Draper, O. D., Knight, K. (2007). Therapeutic Modalities: The Art and Science With Clinical Activities Manual. Baltimore: Lippincott Williams \& Wilkins.

Eek, M. N., Tranberg, R., Zugner, R., Alkema, K., Beckung, E. (2008). Muscle strength training to improve gait function in children with cerebral palsy. Developmental Medicine and Child Neurology, 50, 759-764.

Franjoine, M. R., Gunther, J., Taylor, M. J. (2003). Pediatric Balance Scale: A modified version of the Berg balance scale for the school-age child with mild to moderate motor impairment. Pediatric Physical Therapy, 15, 114-128.

Freeman, M. (2007). Physical Therapy of Cerebral Palsy. New York: Springer.

Grimm, L. G. (2000). Reading and Understanding Multivariate Statistics. Washington: Data Reproductions Corporation.
Katz-Leurer, M., Rotem, H., Keren, O., Meyer, S. (2009). The effects of a "home-based" task-oriented exercise programme on motor and balance performance in children with spastic cerebral palsy and severe traumatic brain injury. Clinical Rehabilitation, 23, 714-724.

Knight, K. (1995). Cryotherapy in Sport Injury Management. Champaign: Human Kinetics.

Latella, D., Meriano, C. (2003). Occupational Therapy Manual for Evaluation of Range of Motion \& Muscle Strength. New York: Thomson Delmar Learning.

Lee, J. H., Sung, I. Y., Yoo, J. Y. (2008). Therapeutic effects of strengthening exercise on gait function of cerebral palsy. Disability and Rehabilitation, 30, 14391444 .

Lee, S. U., Bang, M. S., Han, T. R. (2002). Effect of cold air therapy in relieving spasticity: Applied to spinalized rabbits. Spinal Cord, 40, 167-173.

Majnemer, A., Mazer, B. (1995). New directions in the outcome evaluation of children with cerebral palsy. Seminars in Pediatric Neurology, 11, 11-17.

Manheim, C. J. (2008). The Myofascial Release Manual. Thorofare: SLACK Incorporation.

Mutlu, A., Livanelioglu, A., Gunel, M. K. (2008). Reliability of Ashworth and Modified Ashworth scales in children with spastic cerebral palsy. $B M C$ Musculoskeletal Disorders, 10, 9-14.

Nordmark, E., Hagglund, G., Lagergren J. (2001). Cerebral palsy in southern Sweden. Prevalence and clinical features. Acta Pediatrica Scandinavica, 90, 1271-1276.

Palisano, R., Rosenbaum, P., Walter, S. et al. (1997). Development and reliability of a system to classify gross motor function in children with cerebral palsy. Developmental Medicine and Child Neurology, 39, 214-223.

Paneth, N., Hong, T., Korzeniewski, S. (2006). The descriptive epidemiology of cerebral palsy. Clinics in Perinatology, 33, 251-267.

Russell, D. J., Rosenbaum, P. L., Avery, L. M., Lane, M. (2002). Gross Motor Function Measure (GMFM-88 \& GMFM-66) User's Manual. London: Mac Keith Press.

Salem, Y., Lovelace-Chandler, V., Zabel, R. J., McMillan, A. G. (2010). Effects of prolonged standing on gait in children with spastic cerebral palsy. Physical \& Occupational Therapy in Pediatrics, 30, 54-65.

Stepanchenko, O. V., Semenova, K. A., Vinogradova, L. I. (1988). Artificial local hypothermia in the treatment of children with cerebral palsy. Zhurnal Nevropatologii $i$ Psikhiatrii Im. S. S. Korsakova, 88, 39-42. 


\title{
KRIOTERAPIJOS POVEIKIS VAIKUৃ, SERGANČIŲ CEREBRINIU PARALYŽIUMI, KOJŲ SPAZMIŠKUMUI
}

\author{
Saulė Sipavičenė ${ }^{1}$, Antanas Damašauskas², Irina Klizienė³, Gražina Krutulytė', \\ Aiva Karpavičiené ${ }^{1}$, Tadas Česnaitis ${ }^{4}$ \\ Lietuvos kūno kultūros akademija ${ }^{l}$, Kaunas, Lietuva \\ Vilijampolès socialinès globos namai², Kaunas, Lietuva \\ Kauno technologijos universitetas ${ }^{3}$, Kaunas, Lietuva \\ Lietuvos sveikatos moksly universiteto ligonine Kauno klinikos ${ }^{4}$, Kaunas, Lietuva
}

\begin{abstract}
SANTRAUKA
Tyrimo pagrindimas ir hipoteze். Krioterapija gali sumažinti vaikų, sergančių cerebriniu paralyžiumi, kojų spazmiškumą.

Tikslas - nustatyti krioterapijos poveiki vaiku, sergančiu cerebriniu paralyžiumi, kojų spazmiškumui.

Metodai. Tirti keturiolika 6-12 metų amžiaus vaikai, kuriems diagnozuota cerebrinio paralyžiaus spazminè diplegija. Kontrolinei vaikų grupei $(n=7)$ taikyti fiziniai pratimai, tiriamajai $(n=7)$ - fiziniai pratimai, derinami su krioterapija. Prieš taikytas procedūras ir po jų matuotas visų tiriamujų pẻdos tiesimas, vertinti pẻdos selektyvūs judesiai, pėdos lenkiamuju raumenų spazmiškumas, pusiausvyra ir stambiosios motorikos funkcijos.

Rezultatai. Po fizinių pratimų pagerèjo tiriamuju pėdos tiesimas, sumažèjo pėdos lenkiamujų raumenu spazmiškumas, pagerèjo pėdos selektyvūs judesiai, pusiausvyra ir stambiosios motorikos funkcijos. Tarp tiriamosios ir kontrolinės grupès rezultatų statistiškai patikimas skirtumas nenustatytas.

Aptarimas ir išvados. Krioterapijos poveikis vaikų, sergančių cerebriniu paralyžiumi, kojų spazmiškumui statistiškai nereikšmingas.
\end{abstract}

Raktažodžiai: spazmiškumas, krioterapija, fiziniai pratimai.

Gauta 2012 m. balandžio 25 d.

Received on April 25, 2012

Priimta 2012 m. birželio 8 d.

Corresponding author Saulè Sipavičienė

Accepted on June 8, 2012

Lithuanian Academy of Physical Education

Sporto str. 6, LT-44221 Kaunas

Lithuania

Tel +37061117191

E-mail s.sipaviciene@1kka.1t 